\title{
The Federals in Iowa: A Hawkeye Guidebook in the Making
}

Don Farran

The following is a reminiscence of Mr. Farran's participation in the Federal Writers Project in the late 1930s.-Ed.

THE New York Times recently said of the American Guidebook Series: "They may just be the greatest Guidebooks ever published." In political matters, members of both parties had been stunned by the various and changing relief programs of President Roosevelt and his New Deal advisors. A "third of a nation" was ill-housed and ill-fed; also ill-employed, ill-paid and ill-treated in every other manner. Relief programs tried, from the federal level down through the state level, to provide work programs at minimum pay or less to fill the void created by lack of industrial production and failing agricultural revenues. By 1936-37 recovery appeared to be on its way-recovery, that is, of the political critics of the two primary parties in the United States. The word "boondoggle" had entered the lexicon of common usage in the daily press and in radio broadcasts-even unto many pulpits. If no good could come out of Nazareth, neither could it come out of Washington, D.C.

When it was finally discovered that there were also hungry and sometimes starving writers, artists, musicians, educators-a cultural world now grown more than lean and hungry and never decently nurtured in the past-the Works Progress Administration under an Iowan, Harry Hopkins, started to take some action. He set up the Federal "white-collar" projects to operate through state administrators in the fields of writers, artists, musicians and archives. In short, to the political parties, the Feds had now become involved with something even worse than the leaf-raking in the parks: expenditure of taxpayers' funds to feed and maintain creative talent 
in America. This was intepreted as an insult supreme to the slaving workingmen and the callused-palm farmers, most of whom had no income and no future. Many thought that the men in the White House, scheming for purely political advantage now, had gone too far.

But the Feds remained steadfast in their original goal. Congress had appropriated the funds and the money would be spent, with prudence, it was hoped. Consequently they bought the finest creative talents in America at fire-sale prices: from $\$ 16$ to $\$ 96$ a month for those on the relief rolls, and a little over $\$ 100$ a month for administrative personnel. In most cases, the "wastrels" outrode the storms of political and puritanical attacks, and some culture survived. In the dark medieval ages in Europe it was the monks in the monasteries who, saving some of their food grains for seed for next year's crops, saved humanity from extinction. They too, were on reduced rations.

I was in Boston, recently returned via New York from some time in Brazil and Argentina with Richard Bennett, the actor, while writing his memoirs for a national weekly magazine. Grand opera was to be streamlined for the first time in America by the Boston Federal Music Project, under its State Direotor, Alec Buckingham Simson, with the aid of the famous director of the Chicago Civic Opera, Isaac Van Grove. Alec, an old friend of mine, had invited me to come along, to spend the winter of $1936-37$ with them.

By April, 1937, friends on the Federal Writers Project operating out of Des Moines, felt the urge, or the need, or the risk of asking me to come join them and help share their burden of abuse. Having in the earlier 1930s been the President of the Iowa Authors Club, largest of its kind in the United States, and inured to public scorn and ribald ridicule in that field, the invitation seemed appropriate. Besides, the Federal government in Washington, D.C. had just discovered how much the Federal Music Project in Boston was paying in rental per week for the use of the Boston Opera House and was planning to close down that very successful project. The Boston music critics' reviews had been magnificent, but the lovely Eleanor Steber, singing the operatic leads for $\$ 96$ a month, would be out of work. Three years later.she was 
signed by the Met in New York.

It was in April, 1937, that I took my assigned desk in the make-shift offices of the Federal Writers Project in Des Moines. Jay DuVon, a fine administrator, had been its State Director but had gone on to become the Regional Director. Raymond Kresensky, former minister, writer, poet, literary critic, college student, industrial worker, from Algona, Iowa, had succeeded DuVon as State Director. And it had been Ray, an old friend, who had invited my return to Iowa.

The Project's administrative and editorial staff was small. No one seemed to know exactly how many writers were on it, state-wide, for they were certified for relief in most cases, and they came and went according to some mysterious local community influence. A great many of them were researchers, the gatherers of the woodpile from which the finished product would emerge as a Guidebook covering the entire state.

Professor George Keller, of the Engineering Department of the University of Iowa, had been loaned as State Administrator for the Works Progress Administration in Iowa. At the state level Jessie Hanthorn was in charge of all "white collar" projects. At the national level Mrs. Florence Kerr, also an Iowan, was in charge of such projects as Assistant National Commissioner, with Mrs. Ellen Woodward (Mississippi), under Harry Hopkins. The Federal Writers Project's National Director was Henry G. Alsberg, and in its latter stages was Larry Morris.

The major part of the research had been accomplished prior to my arrival, historical matters concerning cities, towns and counties obtained from well-worn sources, from the earliest county histories to the latest Chamber of Commerce brochures. The resulting conglomeration seemed not too new or exciting to my editorial eyes. The political hand of the national office and WPA in Washington had lain heavily upon the material: nowhere in the material was there intelligence concerning who really framed and passed the state's legislation; which period of the state's life had been controlled by railroads, which by bankers, which by powerful insurance companies, which by public utilities. The whole had been as carefully designed and executed as scrim, which Oriental and other carvers extol in ivories and rare woods. It was just like 
the textbooks in the schools and universities said it was: expedient and proper, and untainted by disbelievers in the functioning of the capitalistic system, or by those disenchanted with the "Establishment" as it is presently known to nonconformists.

The portion of the book concerning cultural matter was dealt with briefly. Artists, writers, poets, musicians and scholars all were called off as if they were on a roster, with an occasional one being given a few paragraphs of eulogy or niggardly praise for his or her accomplishment. We had listed more than 250 bona fide authors in the Iowa Authors Club as having been born or living a great part of their lives within Iowa. Sic transit gloria. The Club never got mentioned; neither did various poetry and arts and music clubs in Iowa. It looked more like a list of potential chautauqua speakers than a record of Iowans' cultural accomplishments.

When I voiced my protest of this shabby treatment of creative people, Ruth Stewart, one of the better editors, hushed me in the fear that those in Washington, D.C. might have long ears even if not Democrats (and a few were not). I questioned their policy of trying to set a pattern into which all Guidebooks must fall in forty-eight states. The term wilco had not yet been invented-I was to learn it as a Navy officer years later.

The larger part of the Guidebook was compiled, again without too much creativity in the organization and writing, of tours, extending along the marked highways from city $A$ to city $\mathrm{B}$, et cetera, et cetera. Major cities and towns along the route would be covered. The smaller towns might get a paragraph or two if the battle of Bunker Hill or the Long Horn occurred there, or some banker-legislator had grown up on a nearby farm. Blizzards and all other natural disasters were in the main ignored, since research seemed to have been accomplished during normally good weather. Population trends which might change the nature of the state and anticipate the need to build additional schools, more highways, and industrial complexes - these apparently were not considered of great importance. That the state itself might one day become half agricultural and half industrial seemed to have occurred to no one. Likewise, implications of such pro- 
jections were not discussed. The main idea was to get in your car, push your foot down, and make the tours at $50 \mathrm{mph}$, probably listening to a baseball game on the car's radio. (And it is still being done that way by today's drivers.)

I had suggested, engagingly, a few walking-tours through rural areas, in the British manner, observing the flora and fauna; even throwing in a dozen or so small towns to get the feel of that kind of life. Kresensky nodded to comfort me and told me Washington had already set the pattern without those embellishments. I then asked why the old county histories were huge volumes for each county but we were to get only one Guidebook to cover the entire state. The answer was the same - Washington said so.

There was, of course, the always-present pressure from Washington to get the volume ready for publication. And, understandably, a sibling rivalry on the part of the other fortyseven states to be the first to hit the bookstands. I suggested one day that each of us write a Guidebook, thereby covering the possibilities and probabilities of the state in-depth and in a sort of point-counterpoint, stream-of-consciousness technique. That day at lunch I was voted the El Dumbo of the project. (The first of the Guidebooks to be published was that for Idaho, written almost entirely by Vardis Fisher, its State Director. It was also one of the best.)

That summer of 1937 was very hot and sticky - in more ways than one. The press in Iowa was fueling up against us. Most of the editors of the smaller county newspapers were fuming at our "futile and wasteful efforts" - interesting comment since we had not yet shown them by publication just what we were doing. The state's largest newspapers, the Des Moines Register-Tribune, sailed a few plates and some pots and pans in our direction in their rainy-day editorials, but we had a good friend over there who would occasionally risk the wrath of the brothers Cowles with a good and sensible editorial emphasizing the need for a Guidebook, its probable and eventual completion by able writers, and pointing out that the project provided employment for the currently unemployed. His name was Ken MacDonald - he runs the papers now.

The academic world was strangely silent about the Fed- 
eral cultural projects, although the University of Iowa had the famous Grant Wood at the head of their graphic and arts projects using federal funds, and the Federal Art Project was creating paintings and murals in government buildings across the state. What should have been a cultural renaissance in Iowa seemed more like a conspiracy of silence, an awkward apology, an imposition upon the "Establishment". But at least the "young rebels" were not burning down the bastilles in order to start anew as in the late 1960s.

Occasionally, during the coffee breaks from the avalanche of materials collected by the researchers from about the state, one did wonder what type of Guidebook might gestate if Washington had given us more freedom from the classical form, and if we had had among us a few Iowa writers who were not a part of the effort. A dozen or so would come to mind. Mackinlay Kantor, for instance, was busily writing his novels between surgery on that bad leg almost every year. Could there have been a place in the Iowa Guidebook for his nostalgia of his Boy Scout troop in earlier years and field trips in autumn; or E. Leslie Spaulding, a poet over in McGregor, who married his wife three times and wrote some of Iowa's finest poetry; or Phil Stong and the Homerian humor of his grandfather in State Fair; or Richard Sherman and the gentleness of his To Mary, With Love novel; or the young Paul Engle and his lovely poems about children; or Harlan Miller and his wife Doris (whose lovely black braids I used to pull in the row ahead of me in Spanish class at the University of Iowa); these and a dozen others and their writing belonged in the Guidebook if it was to be by and for the people.

But they were on the other side of the tracts (pun permitted) at that moment in time, although I had known some of them when they had no coins in their pockets. So the Guidebook stacked up final pages that were sent off to Washington, D.C., a few at a time. It was more than two years from the first work on it until The Viking Press in New York released it to the public through bookstores. I was long-gone from the Writers Project by that time; in fact, my total time with it was measured in a few months. The pay was low but the hours were good and the company was excellent.

Late one Friday afternoon I was called from the Writers 
Project offices to the state office and told to report on the following Monday morning to the state capitol up on the hill. It seemed the barefoot boy from Iowa ... ' had been promoted to become the State Director of the Federal Historical Records Survey project for Iowa, and all this unbeknownst to him until then. My new quarters would be the elaborate mahogany office of the House Speaker (it was between sessions that year), and my new assignment would be to pull together and get some inventory of records publications completed. There would be a staff of some eighty to ninety persons state-wide, varying according to the whims of local certifying boards, most of them well-qualified in the work to be done. What I didn't know was that while at the Writers Project we were dealing with disgruntled editors and politicians, in my new job we would be dealing on a people-topeople basis at local levels. I was to learn that it would be no bed of roses ahead.

By the time the Iowa Guidebook was published I had again been kicked upstairs from the Historical Records Survey to the Federal Theatre Project at the Regional level in Chicago. I bought a copy of the book, felt a great warmth that the job on it had been finished by my old friends, and also felt a little sad that the Washington, D.C. pattern hadn't been broken so some kind of a strange and beautiful butterlly might have emerged. Ruth Suckow, one of Iowa's better novelists, gave it a fine review, at the same time objecting that the book complained about Iowa writers leaving the state to write elsewhere. (She had actually done that herself a few times during her career.)

Why not ask for the Iowa Guidebook at your local library? If you are fortunate enough to find it, note that it sold for $\$ 2.50$ when published; it would sell for $\$ 10$ if published today. The Federal government got all of the Guidebooks at bargain-counter prices. In recent years publishers in New York have offered as high as $\$ 26,000$ for a complete set of them, if you happen to have a full set in your attic or even in your library. 
Copyright of Annals of Iowa is the property of State of Iowa, by \& through the State Historical Society of Iowa and its content may not be copied or emailed to multiple sites or posted to a listserv without the copyright holder's express written permission. However, users may print, download, or email articles for individual use. 